\title{
Summary of the Statement on International Travellers and Typhoid by the Committee to Advise on Tropical Medicine and Travel (CATMAT)
}

\author{
Greenaway $C^{1^{\star}}$, Schofield $S^{2}$, Henteleff $A^{3}$, Plourde $P^{4}$, Geduld $J^{5}$, Abdel-Motagally $M^{5}$ and \\ Bryson $M^{5}$ on behalf of CATMAT
}

\author{
1. Department of Microbiology, McGill University, Montreal, QC \\ 2. Department of National Defense, Ottawa, ON \\ 3. Innovative Solutions - Health Plus, Winnipeg, MB \\ 4. Winnipeg Regional Health Authority, Winnipeg, MB \\ 5. Public Health Agency of Canada, Ottawa, ON \\ *_Corresponding author: ca.greenaway@mcgill.ca
}

\section{Abstract}

Background: Typhoid fever is an enteric febrile illness with symptoms that range from mild to potentially fatal. Among Canadians it is usually acquired during travel to typhoid endemic countries. The Committee to Advise on Tropical Medicine and Travel (CATMAT) assembled a typhoid working group to update recommendations on typhoid and international travel. This document is a summary of the new typhoid statement.

Methods: Following a systematic review of the literature, typhoid vaccine recommendations were developed using the Grading of Recommendations Assessment, Development and Evaluation (GRADE) methodology to evaluate data quality, benefits and harms, and values and preferences. The literature search focused on systematic reviews of typhoid vaccine efficacy and identified studies of disease burden, pathogenesis, risk factors and prevention. Other recommendations were based on a review of the retrieved literature and expert opinion.

Results: Typhoid vaccine is moderately effective ( $50 \%)$, well tolerated, with very low risk of serious adverse events. Studies of typhoid vaccine efficacy, morbidity or mortality among travellers were not found, although studies on populations in typhoid endemic countries were identified. Among travellers, destination of travel is the strongest and most consistent typhoid risk predictor; the highest risk was for travel to South Asia. Confidence in effect estimates for other potential risk factors was very low.

Recommendations: CATMAT suggests that typhoid vaccine (Ty21a or Vi polysaccharide vaccine) be used for most Canadian travellers visiting South Asia and not used for most Canadian travellers visiting destinations other than South Asia. The recommendations are conditional, due to the moderate confidence in the effect estimate. For destinations other than South Asia, providers should discuss risks and vaccine benefits and harms with the traveller as well as recommend basic hygiene precautions.

\section{Introduction}

Typhoid fever is an enteric febrile illness caused by Salmonella enterica subsp. enterica serovars Typhi (S. typhi) $(1 ; 2)$. Humans are the only reservoir for this disease and exposure to the causative pathogen is usually through ingestion of water or food that has been contaminated by feces from an ill individual or a chronic carrier (3;4). Prevention involves vaccination, personal hygiene and food and water precautions.

The World Health Organization (WHO) estimates 21 million typhoid cases and 210,000 to 840,000 deaths annually worldwide $(5 ; 6)$. In endemic countries, widespread transmission is facilitated by poorly developed sanitation infrastructure (7). Most cases and deaths (more than 90\%) occur in Asian countries, predominantly in South Asia (5). Incidence in high income countries is low (e.g., $<15 / 100,000$ persons per year) $(1 ; 3 ; 8)$ and usually acquired during travel (9-12). 
The clinical course of typhoid ranges from mild illness (low-grade fever) to severe systemic potentially fatal disease $(2 ; 3)$. The case fatality rate is approximately $10 \%$ for untreated cases in low income settings and $<1 \%$ for patients receiving care in high income countries (13-17).

The Committee to Advise on Tropical Medicine and Travel (CATMAT) provides the Public Health Agency of Canada with ongoing and timely medical, scientific, and public health advice relating to tropical infectious disease and health risks associated with international travel. This is a summary of the CATMAT Statement on International Travellers and Typhoid where a full description of the evidence and recommendations is available (18).

\section{Methods}

This is the first CATMAT statement to use the Grading of Recommendations Assessment, Development and Evaluation (GRADE) methodology to develop recommendations (19). GRADE is a new method of grading the quality of the evidence and strength of recommendations in guidelines used by many international organizations.

\section{Literature search and identification}

An analytic framework identifying clinical preventive actions (interventions) for typhoid and risk factors for typhoid disease was developed. Key questions to define the magnitude of benefits and harms were identified as well as the following key "PICO" (population of interest, intervention, comparison and outcome) question:

\section{Among Canadian travellers, does the administration of typhoid vaccine versus no vaccine decrease the incidence of typhoid and the associated morbidity and mortality?}

Two types of typhoid vaccine are licensed in Canada, a live oral vaccine (Ty21a), and injectable Vi polysaccharide vaccines (Table 1). Only evidence for these types of vaccines was reviewed.

Relevant literature was identified by searching Ovid MEDLINE and Embase electronic databases using the terms "typhoid fever" and "travel". The search spanned publications from January 1, 2000 to August 14, 2012. In addition, the Cochrane Database of Systematic Reviews was searched using the term "typhoid" from the start of the database up to and including July 2012. For all searches, only English and/or French articles were retained.

Systematic reviews that addressed the efficacy of typhoid vaccine were specifically sought. Studies that addressed burden of disease (incidence, morbidity, mortality, hospitalizations), especially for travellers; disease pathogenesis; population-specific risk factors (e.g., age, travellers visiting friends and relatives (VFR)); itineraryspecific risk factors (e.g., destination, duration of travel); efficacy of preventive measures (e.g., sanitation and hygiene); and/or disease treatment/management were also identified. 
Table 1: Typhoid vaccines licensed for use in Canada

\begin{tabular}{|c|c|c|c|}
\hline Vaccine & $\begin{array}{l}\text { Parenteral, capsular } \\
\text { polysaccharide vaccines } \\
\text { (Typh-I) }\end{array}$ & $\begin{array}{l}\text { Oral, live attenuated } \\
\text { vaccine (Typh-O) }\end{array}$ & Combined vaccine \\
\hline Brand Name & $\begin{array}{l}\text { Typhim Vi }{ }^{\circledR}(20) \text { (Sanofi } \\
\text { Pasteur) } \\
\text { TYPHERIX }{ }^{\circledR}(21) \\
\text { (GlaxoSmithKline Inc) }\end{array}$ & $\begin{array}{l}\text { Vivotif }{ }^{\circledR} \text { (capsules) (22) } \\
\text { (Crucell Switzerland Ltd) }\end{array}$ & $\begin{array}{l}\operatorname{ViVAXIM}^{\circledR}(23) \text { (Sanofi Pasteur) } \\
\text { (combination of purified Vi } \\
\text { polysaccharide typhoid with } \\
\text { inactivated hepatitis } \mathrm{A} \text { ) }\end{array}$ \\
\hline $\begin{array}{l}\text { Authorized for use in } \\
\text { persons }\end{array}$ & $>2$ years of age & $\begin{array}{l}\text { adults and children }>5 \text { years } \\
\text { of age }\end{array}$ & $\geq 16$ years of age \\
\hline Protection begins & 14 days following vaccination & 7 days following vaccination & 14 days following vaccination \\
\hline Dosage & $0.5 \mathrm{ml}$ & $\begin{array}{l}4 \text { enteric-coated capsules } \\
\text { taken on alternate days }\end{array}$ & $1.0 \mathrm{ml}$ \\
\hline Route & Single intramuscular injection & Orally in a series of doses & Single intramuscular injection \\
\hline Contraindications & $\begin{array}{l}\text { A severe local or systemic } \\
\text { reaction to a previous dose of } \\
\text { the vaccine }\end{array}$ & $\begin{array}{l}\text { Individuals with hypersensitivity } \\
\text { to any component of the } \\
\text { vaccine or the enteric-coated } \\
\text { capsule. } \\
\text { Persons with an acute } \\
\text { gastrointestinal condition or } \\
\text { inflammatory bowel disease. } \\
\text { Vaccine should not be } \\
\text { administered to persons } \\
\text { deficient in their ability to } \\
\text { mount a humoral or cell- } \\
\text { mediated response due to } \\
\text { either a congenital or acquired } \\
\text { immunodeficient state } \\
\text { including treatment with } \\
\text { immunosuppressive or } \\
\text { antimitotic drugs. }\end{array}$ & $\begin{array}{l}\text { Known systemic hypersensitivity } \\
\text { reaction to any component of } \\
\text { ViVAXIM }^{\circledR} \text { or a life-threatening } \\
\text { reaction after previous } \\
\text { administration of the vaccine or a } \\
\text { vaccine containing one or more of } \\
\text { the same components }\end{array}$ \\
\hline Drug Interactions & $\begin{array}{l}\text { There are no known } \\
\text { interactions }\end{array}$ & $\begin{array}{l}\text { Antibiotics: Ty21a vaccination } \\
\text { should be completed } 3 \text { days } \\
\text { before commencing treatment } \\
\text { with sulfonamides or other } \\
\text { antibiotics. } \\
\text { Antibiotic exceptions: } \\
\text { Chloroquine, Mefloquine and } \\
\text { Malarone do not influence the } \\
\text { immune response of Ty21A } \\
\text { and can be administered at } \\
\text { any interval. } \\
\text { When using any other } \\
\text { antimalarial, immunization with } \\
\text { Vivotif }{ }^{\circledR} \text { should precede } \\
\text { antimalarial prophylaxis using } \\
\text { the } 3 \text { day interval. }\end{array}$ & \\
\hline Adverse Events & $\begin{array}{l}\text { Typhim } \mathrm{Vi}^{\circledR} \text { :Pain at injection } \\
\text { site, edema, redness, } \\
\text { headache and malaise (20) } \\
\text { TYPHERIX }{ }^{\circledR} \text { Pain at injection } \\
\text { site, fever, headache, general } \\
\text { aches, malaise, nausea and }\end{array}$ & $\begin{array}{l}\text { Adverse reactions are } \\
\text { infrequent and mild; nausea, } \\
\text { abdominal pain, headache, } \\
\text { fever, diarrhea, vomiting and } \\
\text { skin rash. }\end{array}$ & $\begin{array}{l}\text { ViVAXIM }^{\circledast} \\
\text { Pain, edema or erythema at the } \\
\text { injection site, myalgia, headache, } \\
\text { fever, malaise, nausea and } \\
\text { diarrhea (23). }\end{array}$ \\
\hline
\end{tabular}




\begin{tabular}{|c|c|c|c|}
\hline Vaccine & $\begin{array}{l}\text { Parenteral, capsular } \\
\text { polysaccharide vaccines } \\
\text { (Typh-I) }\end{array}$ & $\begin{array}{l}\text { Oral, live attenuated } \\
\text { vaccine (Typh-O) }\end{array}$ & Combined vaccine \\
\hline & $\begin{array}{l}\text { itching. } \\
\text { These mild reactions occur in } \\
\text { less than } 10 \% \text { of individuals } \\
\text { vaccinated }(21) \text {. }\end{array}$ & & \\
\hline $\begin{array}{l}\text { Efficacy with } \\
\text { immunosuppression }\end{array}$ & $\begin{array}{l}\text { Immunocompromised persons } \\
\text { (whether from disease or } \\
\text { treatment) may not obtain the } \\
\text { expected immune response. }\end{array}$ & & \\
\hline Revaccination $^{a}$ & $\begin{array}{l}\text { TyphimVi - every } 3 \text { years } \\
\text { TYPHERIX }{ }^{\circledR} \text { - every } 3 \text { years }\end{array}$ & $\operatorname{Vivotif}^{\circledR}$ - every 7 years ${ }^{b}$ & $\begin{array}{l}\text { Hepatitis A - Boost with a single } \\
\text { dose of inactivated hepatitis A } \\
\text { vaccine } 6-36 \text { months later for long } \\
\text { term protection. } \\
\text { Typhoid - Revaccination with a } \\
\text { single dose of purified } \mathrm{Vi} \\
\text { polysaccharide vaccine can be } \\
\text { given at an interval of not more } \\
\text { than } 3 \text { years. }\end{array}$ \\
\hline Interchangeability & \multicolumn{3}{|c|}{$\begin{array}{l}\text { Although there are no data regarding the interchangeability of typhoid vaccines, it is presumed that re- } \\
\text { immunization can be performed with any of the available formulations regardless of the vaccine used } \\
\text { initially. }\end{array}$} \\
\hline Safety in Pregnancy & \multicolumn{3}{|c|}{$\begin{array}{l}\text { Safety in pregnancy has not been studied for any of the typhoid vaccines. Therefore, the benefits of } \\
\text { vaccination must be carefully weighed against potential adverse events before it is given to pregnant } \\
\text { women. Vaccine should only be used in pregnancy when there is a high risk of infection. There is no } \\
\text { expected effect with purified polysaccharide vaccines. }\end{array}$} \\
\hline
\end{tabular}

Sources: (20-23)

${ }^{a}$ Revaccination should be carried out when subjects remain at risk in conditions of repeated or continuous exposure. The Cochrane review presented data that sero protection continues for up to three years after immunization in endemic populations; there are data to indicate that protection from Ty21a extends to 7 years (24). There are no data on continued protection in travellers.

bCATMAT is aware that The Yellow Book - CDC Health Information for International Travellers 2012 advises repeat immunization with oral live attenuated Ty21a vaccine every 5 years however the CATMAT statement is consistent with the Health Canada Biologics and Genetic Therapies Directorate vaccine approval for re-immunization every 7 years.

\section{Assessment of evidence}

Full details on GRADE methodology are described elsewhere (25). Briefly, the GRADE approach rates the quality of the evidence for specific clinical outcomes across studies, not study by study, by addressing flaws in methodology, consistency and generalizability of results and demonstrated effectiveness of the treatment $(26 ; 27)$. The GRADE approach takes into consideration the balance of benefits (efficacy) and harms of typhoid vaccine, the confidence in the estimates of effect for vaccination (high, moderate, low or very low), and what is believed to be the values and preferences of the traveller. GRADE quality assessments of studies of typhoid vaccine efficacy, vaccine adverse events and typhoid risk by destination region were performed, and results were collated into evidence profile and summary of findings tables (18).

In this statement, recommendations are expressed as strong or conditional as outlined in the Appendix. Other recommendations, not using the GRADE approach, do not use this terminology. These recommendations were based on evaluation of the relevant literature and expert opinion. 


\section{Results}

In total, 147 articles met the language and relevancy criteria and were included. Two additional studies on baseline risk $(28 ; 29)$ were identified after the initial literature review.

\section{Vaccine efficacy}

No studies that addressed efficacy of typhoid vaccine in travellers or associated reductions in morbidity and mortality for this population were found. All included vaccine efficacy studies were conducted in populations living in typhoid endemic countries. A 2006 Cochrane Collaboration systematic review assessed 17 randomized or quasi-randomized trials (30) of typhoid vaccine among residents of endemic areas. An additional three randomized or quasi-randomized controlled clinical trials published after this systematic review were also identified and included in this analysis (31-33).

Expressed as three year cumulative risk of typhoid, persons receiving typhoid vaccine (Ty21a or Vi polysaccharide) were significantly less likely to develop typhoid fever than those who did not (Relative Risk (RR), $95 \% \mathrm{Cl}=0.51$ (0.42 to 0.62$)$ ). For the same outcome, but measured as a two year cumulative risk of typhoid, RR was lower at 0.43 ( 0.34 to 0.54 ). Expressed by vaccine type, estimates ranged from $R R=0.34$ ( 0.19 to 0.60 ) for Ty21a after two years of follow-up to $0.53(0.43$ to 0.54$)$ for Ty 21 a after three years of follow-up; efficacy of $\mathrm{Vi}$ polysaccharide vaccine was intermediate to these values. Vaccine efficacy for different age groups was assessed separately by vaccine type as results were reported with different age stratifications. For both types of vaccine, the RR estimate was lower in older than in younger persons. However, these differences were not significant.

Estimates of effect were without serious risk of bias; but were rated down for indirectness as they only included residents of endemic areas (not travellers) and often were limited to younger age groups. There was moderate confidence in the estimate of effect for vaccine efficacy. No data on the impact of typhoid vaccination on morbidity and mortality were found.

\section{Adverse events associated with vaccine}

Based on clinical trial data, adverse events $(A E)$ associated with typhoid vaccines are generally mild and not significantly different from controls for: fever, vomiting, diarrhea, headaches, rash, or erythema. With $\mathrm{Vi}$ polysaccharide, pain at the injection site was more common among the vaccine recipients ( $R R=3.68$; $(1.96$ to 6.93)). For enteric coated Ty21a, there was increased risk of: any mild adverse event (RR=1.78; (1.08 to 2.95)) (30) and nausea or abdominal pain $(R R=2.13 ;(1.33$ to 3.41)). Based on these data, it was estimated that there would be one additional $A E$ due to pain for every 13 persons receiving Vi polysaccharide vaccine; and one mild $\mathrm{AE}$ and one nausea and abdominal pain $\mathrm{AE}$ for every 18 and 31 persons, respectively, receiving Ty21a.

\section{Risk factors}

The strongest and most consistent predictor of typhoid risk in travellers is destination of travel. The estimated risk of developing travel associated typhoid is about: 1/3,000 travellers for travel to the South Asia (high risk), 1/50,000-100,000 for travel to Sub-Saharan Africa, North Africa and the Middle East, or South America (intermediate risk), and $<1 / 300,000$ for travel to the Caribbean and Central America (low risk). South Asia is defined as Afghanistan, Bangladesh, Bhutan, India, Nepal, Maldives, Pakistan, and Sri Lanka. Among these countries, the large majority $(\geq 90 \%$ ) of cases of typhoid among travellers were reported from India, Pakistan and Bangladesh.

The confidence in the baseline estimates of typhoid risk by destination was reduced from high to moderate because of risk of bias due to possible under-ascertainment of cases and imprecision (i.e. unable to calculate confidence intervals due to incomplete stratified denominator data).

Several studies have identified other factors that increase the risk of travel associated typhoid, including travelling children, those visiting friends and relatives (VFRs), the presence of achlorhydria or use of acid suppression 
therapy and longer duration of travel. The incremental magnitude of risk that these factors contribute in addition to travel destination is unclear.

\section{Values and preferences}

There is evidence that typhoid vaccine is cost effective for residents of some endemic areas $(34 ; 35)$. However, cumulative risk is much higher among resident populations, and it is not appropriate to extrapolate costeffectiveness to travellers paying for their own vaccine. No studies on traveller values and preferences or "Willingness to Pay" for typhoid (36) or other travel-related immunizations were identified. In the absence of data, it was estimated that the majority of Canadian travellers would consider typhoid vaccine use worth the cost and inconvenience where the risk of typhoid is estimated to be greater than 1 in 10,000 travellers, although at the individual level this decision may be influenced by other risk factors.

\section{Antimicrobials}

The WHO considers fluoroquinolones to be the first line agents for typhoid treatment $(37 ; 38)$. In a 2011 Cochrane review, fluoroquinolones were found to result in fewer clinical failures compared to chloramphenicol, cotrimoxazole, amoxicillin and ampicillin (37). When the performance of quinolones was compared to other agents including cephalosporins (ceftriaxone and cefixime) or azithromycin, clinical outcomes appeared to be equivalent in most studies. Definitive conclusions could not be made as most of the data came from small underpowered studies and resistance patterns differ between geographic regions and over time. When deciding on the optimal empiric therapy for typhoid, antibiotic resistance patterns in the travel destination countries should be considered $(3 ; 39)$. Of particular importance is the increasing prevalence of fluoroquinolone resistance among Salmonella tyhpi isolates from Asia (37).

\section{Hygiene interventions}

Interventions such as hand washing and avoiding high risk foods entail minimal or no risk, inconvenience, or cost, and there is appreciable indirect evidence of benefit in terms of reducing typhoid incidence (38).

\section{Typhoid vaccine and Salmonella paratyphi}

Paratyphoid fever, caused by Salmonella enterica serovar Paratyphi A, B and C, is a systemic disease with clinical features indistinguishable from typhoid fever. The global burden, estimated at 5.4 million cases annually, may be increasing (6); as is the prevalence of antibiotic resistance and the number of travel-related cases. It is unlikely that injectable Vi vaccines would provide protection because the vaccine elicits antibodies for an antigen that is not present in $S$. paratyphi A and B. In contrast, Ty21a vaccines elicit serum and mucosal antibodies to $S$. typhi $\mathrm{O}, \mathrm{H}$ and other antigens, which are shared with $\mathrm{S}$. paratyphi. However, current evidence is not sufficient to recommend oral typhoid vaccine (Ty21a) for protection against paratyphoid.

\section{Recommendations and conclusions}

The risk of typhoid to travellers is generally low and varies by region. It is highest for travellers to South Asia. The low risk of typhoid combined with the moderate efficacy of the vaccine mean that the benefits of vaccination are modest (efficacy $\sim 50 \%$ ); however, the vaccines have a good safety profile. Following the review of all evidence and taking into consideration the vaccine efficacy, risk for typhoid and safety profile, CATMAT suggests that the majority of travellers to the South Asia be given typhoid vaccine (Ty21a or Vi polysaccharide vaccine) and not be used for travellers to all other endemic areas (Table 2). The recommendations are conditional, due to the moderate confidence in the effect estimate. 
Table 2: Recommendations on the use of typhoid vaccine for Canadian travellers

\begin{tabular}{|c|c|}
\hline \multicolumn{2}{|l|}{ Typhoid vaccine } \\
\hline \multirow[t]{2}{*}{ CATMAT suggests } & $\begin{array}{l}\text { - that typhoid vaccine (Ty21a or Vi polysaccharide vaccine) be used for Canadian } \\
\text { travellers visiting South Asia*; } \\
\text { Conditional recommendation, moderate confidence in estimate of effect. } \\
\text { that typhoid vaccine (Ty21a or Vi polysaccharide vaccine) not be used for Canadian } \\
\text { travellers visiting destinations other than the South Asia; } \\
\text { Conditional recommendation against immunization, moderate confidence in } \\
\text { estimate of effect. }\end{array}$ \\
\hline & $\begin{array}{l}{ }^{*} \text { For destinations other than South Asia, typhoid vaccination decisions might be influenced by other } \\
\text { factors associated with risk of travel acquired typhoid. Providers should discuss associated risk } \\
\text { factors and anticipated vaccination benefits and harms with the traveller. }\end{array}$ \\
\hline \multicolumn{2}{|c|}{ "Best practice" or "common sense" recommendations: } \\
\hline CATMAT suggests & $\begin{array}{l}\text { - Practitioners should advise travellers to adhere to basic sanitation and food and water } \\
\text { - } \text { Precautions. } \\
\text { (including financial costs) associated with vaccination, and support the traveller in } \\
\text { reaching a decision that is consistent with his/her values and preferences. } \\
\text { - While there is evidence that suggests Ty21a protects against paratyphoid, it is not } \\
\text { sufficient to recommend this vaccine (as an unlabelled use) for this purpose. } \\
\text { - The first line drug of choice to treat typhoid are fluoroquinolones however, local } \\
\text { antimicrobial resistance patterns in the country of travel need to be considered when } \\
\text { choosing empiric therapy. }\end{array}$ \\
\hline
\end{tabular}




\section{References}

(1) Bhutta ZA. Typhoid fever: current concepts. Infect Dis Clin Pract 2006 Sep;14(5):266-72.

(2) World Health Organization. International travel and health. Italy: World Health Organization; 2011.

(3) American Public Health Association. Control of communicable diseases manual, 19th Edition, edited by Heymann, D.L. $19^{\text {th }}$ ed. Washington: American Public Health Association; 2008.

(4) Thaver D, Zaidi A, Critchley J, Azmatullah A, Madni S, Bhutta Z. Fluoroquinolones for treating typhoid and paratyphoid fever (enteric fever). Cochrane Database Syst Rev 2008;4 CD004530.

(5) Crump JA, Luby SP, Mintz ED. The global burden of typhoid fever. Bull World Health Organ 2004 May;82(5):346-53.

(6) Crump JA, Mintz ED. Global trends in typhoid and paratyphoid fever. Clin Infect Dis 2010 Jan 15;50(2):241-6.

(7) Luxemburger C, Duc CM, Lanh MN, Wain J, Hien TT, Simpson JA, et al. Risk factors for typhoid fever in the Mekong delta, southern Viet Nam: a case-control study. Trans R Soc Trop Med Hyg 2001;95(1):19-23.

(8) Connor BA, Schwartz E. Typhoid and paratyphoid fevers in travellers. Lancet Infect Dis 2005 Oct;5(10):623-8.

(9) Gupta SK, Medalla F, Omondi MW, Whichard JM, Fields PI, Gerner-Smidt P, et al. Laboratory-based surveillance of paratyphoid fever in the United States: travel and antimicrobial resistance. Clin Infect Dis 2008 Jun 1;46(11):1656-63.

(10) Keddy KH, Smith AM, Sooka A, Ismail H, Oliver S. Fluoroquinolone-resistant typhoid, South Africa. Emerg Infect Dis 2010 May;16(5):879-80.

(11) Luxemburger C, Dutta AK. Overlapping epidemiologies of hepatitis A and typhoid fever: the needs of the traveler. J Travel Med 2005 Apr;12(Suppl 1):S12-S21.

(12) Steele $D$. The importance of generating evidence on typhoid fever for implementing vaccination strategies. J Infect Dev Ctries 2000 Aug 30;2(4):250-2.

(13) Mermin JH, Townes MJ, Gerber M, Dolan N, Mintz ED, Tauxe RV. Typhoid fever in the United States, 19851994. Arch Intern Med 1998 Mar 23;158(6):633-8.

(14) Lynch MF, Blanton EM, Bulens S, Polyak C, Vojdani J, Stevenson J, et al. Typhoid fever in the United States, 1999-2006. JAMA 2009 Aug 26;302(8):859-65.

(15) Gil R, Alvarez JL, Gomez C, Alvaro A, Gil A. Epidemiology of typhoid and paratyphoid fever hospitalizations in Spain (1997-2005). Hum Vaccin 2009 Jun;5(6):420-4.

(16) Delmas G, Vaillant V, Jourdan N, Hello S., Weill F-X, Valk H. Les fièvres typhoïdes et paratyphoïdes en France entre 2004 et 2009. Bulletin épidémiologique hebdomadaire 2011;2(25 janvier 2011):9-13.

(17) Stuart BM, Pullen RL. Typhoid: clinical analysis of three hundred and sixty cases. Arch Intern Med 1946 Dec;78(6):629-61.

(18) Committee to Advise on Tropical Medicine and Travel (CATMAT). Statement on International Travellers and Typhoid. 2014. http://publications.gc.ca/site/eng/460371/publication.html

(19) Guyatt GH, Oxman AD, Schunemann HJ, Tugwell P, Knottnerus A. GRADE guidelines: a new series of articles in the Journal of Clinical Epidemiology. J Clin Epidemiol 2011 Apr;64(4):380-2.

(20) sanofi pasteur. Typhim Vi Product Monograph. Sanofi Pasteur Limited; 2005.

(21) GlaxoSmithKline Inc. Typherix Product Monograph. GlaxoSmithKline Inc; 2011.

(22) Crucell Switzerland LTD. Vivotif® Product Monograph . 2010.

(23) sanofi pasteur. ViVaxim Product Monograph. Sanofi Pasteur Limited; 2010. 
(24) Levine MM, Ferreccio C, Abrego P, San MO, Ortiz E, Cryz S. Duration of efficacy of Ty21a, attenuated Salmonella typhi live oral vaccine. Vaccine 1999;17:S22-S27.

(25) Balshem H, Helfand M, Schunemann HJ, Oxman AD, Kunz R, Brozek J, et al. GRADE guidelines: 3. Rating the quality of evidence. J Clin Epidemiol 2011 Apr;64(4):401-6.

(26) Guyatt GH, Oxman AD, Santesso N, Helfand M, Vist G, Kunz R, et al. GRADE guidelines 12. Preparing Summary of Findings tables-binary outcomes. J Clin Epidemiol 2012 May 18.

(27) Guyatt GH, Oxman AD, Sultan S, Glasziou P, Akl EA, Alonso-Coello P, et al. GRADE guidelines: 9. Rating up the quality of evidence. J Clin Epidemiol 2011 Dec;64(12):1311-6.

(28) Baaten GG, Sonder GJ, Van Der Loeff MF, Coutinho RA, Van Den Hoek A. Fecal-orally transmitted diseases among travelers are decreasing due to better hygienic standards at travel destination. J Travel Med 2010 Sep;17(5):322-8.

(29) Keller A, Frey M, Schmid H, Steffen R, Walker T, Schlagenhauf P. Imported typhoid fever in Switzerland, 1993 to 2004. J Travel Med 2008;15(4):248-51.

(30) Fraser A, Goldberg E, Acosta CJ, Paul M, Leibovici L. Vaccines for preventing typhoid fever (Review). Cochrane Database Syst Rev 2007;3 CD001261.

(31) Sur D, Ochiai RL, Bhattacharya SK, Ganguly NK, Ali M, Manna B, et al. A cluster-randomized effectiveness trial of Vi typhoid vaccine in India. N Engl J Med 2009 Jul 23;361(4):335-44.

(32) Zhou WZ, Koo HW, Wang XY, Zhang J, Park JK, Zhu F, et al. Revaccination with locally-produced Vi typhoid polysaccharide vaccine among Chinese school-aged children: safety and immunogenicity findings. Pediatr Infect Dis J 2007 Nov;26(11):1001-5.

(33) Khan MI, Soofi SB, Ochiai RL, Habib MA, Sahito SM, Nizami SQ, et al. Effectiveness of Vi capsular polysaccharide typhoid vaccine among children: a cluster randomized trial in Karachi, Pakistan. Vaccine 2012 Aug 3;30(36):5389-95.

(34) Cook J, Sur D, Clemens J, Whittington D. Evaluating investments in typhoid vaccines in two slums in Kolkata, India. J Health Popul Nutr 2009 Dec;27(6):711-24.

(35) Cook J, Jeuland M, Whittington D, Poulos C, Clemens J, Sur D, et al. The cost-effectiveness of typhoid Vi vaccination programs: calculations for four urban sites in four Asian countries. Vaccine 2008 Nov 25;26(50):6305-16.

(36) Whittington D, Sur D, Cook J, Chatterjee S, Maskery B, Lahiri M, et al. Rethinking Cholera and Typhoid Vaccination Policies for the Poor: Private Demand in Kolkata, India. World Development 2009;37(2):399409.

(37) Effa EE, Lassi ZS, Critchley JA, Garner P, Sinclair D, Olliaro PL, et al. Fluoroquinolones for treating typhoid and paratyphoid fever (enteric fever). Cochrane Database Syst Rev 2011;(10):CD004530.

(38) World Health Organization. Background document: The diagnosis, treatment and prevention of typhoid fever. 2003.

(39) World Health Organization. Typhoid vaccines: WHO position paper. Wkly Epidemiol Rec 2008;6(83):49-60.

(40) Schunemann HJ, Brozek J, Oxman AD, editors. GRADE handbook for grading quality of evidence and strength of recommendations. Version 3.2 [updated March 2009]. 2009. The GRADE Working Group.

(41) Andrews J, Guyatt G, Oxman AD, Alderson P, Dahm P, Falck-Ytter Y, et al. GRADE guidelines: 14. Going from evidence to recommendations: the significance and presentation of recommendations. J Clin Epidemiol 2013 Jul;66(7):719-25.

(42) Andrews JC, Schunemann HJ, Oxman AD, Pottie K, Meerpohl JJ, Coello PA, et al. GRADE guidelines: 15. Going from evidence to recommendation-determinants of a recommendation's direction and strength. J Clin Epidemiol 2013 Jul;66(7):726-35. 


\section{Acknowledgements}

CATMAT acknowledges and appreciates the contribution of Dr. Gordon Guyatt, Distinguished Professor of Medicine, McMaster University, GRADE methodological support.

CATMAT members: Dr. A. McCarthy (Chair), Dr. A. Boggild, Dr. J Brophy, Dr. Y. Bui, Dr. M. Crockett, Dr. W. Ghesquiere, Dr. C. Greenaway, Ms A. Henteleff, Dr. M. Libman, Dr. P. Teitelbaum.

Liaison members: Dr. C. Hui (Canadian Paediatric Society), Dr. G. Brunette (US Centers for Disease Control and Prevention).

Ex-officio members: Dr. P. MacDonald (Division of Anti-Infective Drugs, Health Canada), Dr. M. Tepper (Directorate of Force Health Protection, Department of National Defence), Dr. P. Charlebois (Canadian Forces Health Services Centre, Department of National Defence), Dr. S. Schofield (Directorate of Force Health Protection, Department of National Defence).

Member Emeritus: Dr. C.W.L. Jeanes.

\section{Conflict of interest}

There are no conflicts of interest to declare.

\section{Funding}

This work was supported by the Public Health Agency of Canada. 


\section{Appendix}

\section{Recommendation categories}

Strong* recommendation for

The committee believes that all or almost all well informed people would want the recommended course of action and only a small number would not.

Implication for practitioners: The balance of risks and benefits are such that most travellers would choose the intervention.

\section{Strong recommendation against}

Conditional** recommendation for

Conditional recommendation against
The committee believes that all or almost all well informed people would not want the recommended course of action and only a small number would.

Implication for practitioners: The balance of risks and benefits are such that most travellers would not choose the intervention.

The committee believes that the majority of well-informed people would want the recommended course of action, but a minority (perhaps a large minority) would not. Implication for practitioners: With a conditional recommendation different travellers may make different choices. Practitioners should present the risks and benefits of the intervention and help each traveller make a decision consistent with his/her values and preferences.

The committee believes that the majority of well-informed people would not want the recommended course of action, but a minority (perhaps a large minority) would. Implication for practitioners: With a conditional recommendation different travellers may make different choices. Practitioners should present the risks and benefits of the intervention and help each traveller make a decision consistent with his/her values and preferences.

Adapted from the GRADE handbook for grading quality of evidence and strength of recommendations and GRADE guidelines 14 and 15 (40-42).

*The GRADE working group suggests that if a recommendation is "strong", then it is expected that $90 \%$ or more of informed individuals would choose (or not choose) the recommended course of action.

** The GRADE working group suggests that if a recommendation is "conditional", then it is expected that less than $90 \%$ of informed individuals would choose (or not choose) the recommended course of action. 